\title{
BNWL-778 10
}

\section{ENV IRONMENTAL SURVEILLANCE IN THE VICINITY OF HANFORD FOR OCTOBER, 1968}

DECEMBER 30, 1968

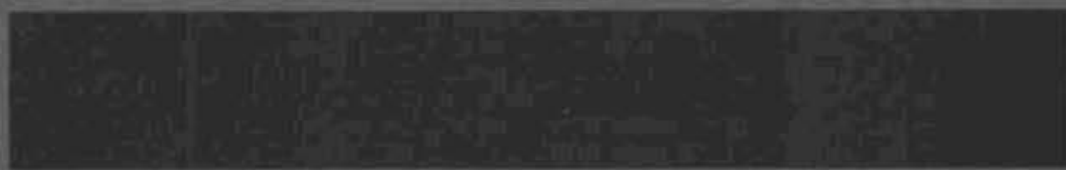

\section{AEC RESEARCH \& DEVELOPMENT REPORT}

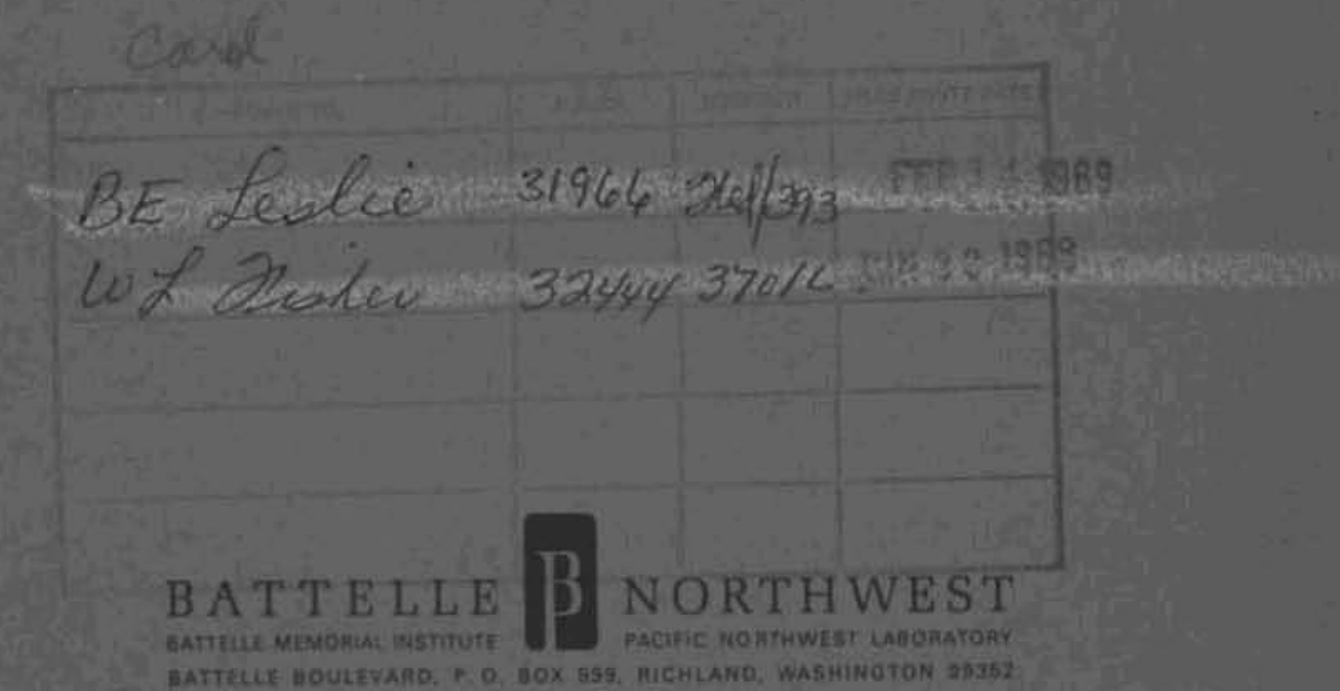




\section{LEGAL NOTICE}

This report was prepored os an account of Government sponsoted work. Naither the United States, not the Commission, nor any person asting on behalf of the Commission:

A. Makes any wartonty or representation, expressed or implied, with respect to the occuracy, completeness, or usefulness of the information contained in this report, or that the use of any Information, apparotus, method, or process disclased in this report may nal infringe privataly owned tights; or

B. Assumes any liabilities with respect to the use of, or for damages resulting fram the use of any information, apparatus, method, of process disclosed in this report.

As used in the above, "person acting on behalf of the Commission" includes any employes or contractor of the Commission, or employee of such contractor, to the extent that such employee or contractor of the Commission, or employee of such controctor prepares, dissemincites, or provides access to, any information pursuant to his employment or controct with the Commission, or his employment weith such contractor:

\section{PACIFIC NORTHWEST LABORATORY RICHLAND, WASHINGTON \\ operated by \\ BATTELLE MEMORLAL INSTITUTE}

for the

UNITED STATES ATOMIC ENERGY COMMISSION UNDER CONTRACT AT(45-1)-1830 
BNWL-778-10

UC-4I

Health and Safety

(Special Distribution)

ENVIRONMENTAL SURVEILLANCE IN THE

VICINITY OF HANFORD FOR OCTOBER, 1968

By

Environmental Evaluations

Radiation Protection

TECHNICAL SERVICES DIVISION

Edited by

C。B。Wooldridge

Disi. ...... 14 269

December 30, 1968

PACIFIC NORTHWEST LABORATORY

RICHLAND, WASHINGTON

UINCLASSIFIED 
ENVIRONMENTAL SURVEILLANCE IN THE

VICINITY OF HANFORD FOR OCTOBER, 1968

INTRODUCTION

This report contains information related to radioactive materials in the Columbia River, the atmosphere, and selected foods (Figures 1-17) for October. 1968. Measurements of the Columbia River flow rate, temperature, and chemical characteristics are also shown (Figures 5, 18-21 and Table 1)。 Data for the previous twelve months is included。

A comprehensive evaluation of these data is reported once per year in an annual report (see BNWLw 439. "Evaluation of Radiological Conditions in the Vicinity of Hanford for 1966")。 The data are updated at midyear and are published in a semi-annual report (see BNWL-665. "Evaluation of Radiological Conditions in the Vicinity of Hanford, January-June, 1967")。

The radiochemical data presented in this report were supplied by the $U_{0} S_{0}$ Testing $\mathrm{Co}_{0}$. Inc, which performed the routine radioassays of environmental samples。 The "analytical limit", as used on some of the figures in this report, is defined as the concentration at which the laboratory can measure a radionuclide with an accuracy of \pm 100 percent at the 90 percent confidence level. The detection limit for a specific radionuclide varies with sample type sample size, counting time, and the amounts of interfering radionuclides present. The "analytical limits" were chosen to represent upper bounds to these fluctuating detection limits. Many of the graphs do not show the "analytical limit" because. for certain analyses, these limits are below the range of values shown on the graphs。

\section{SUMMARY}

The concentrations of most radionuclides in the Hanford environs during October, 1968, were at or below comparable 1967 values. The average shoreline exposure rate as measured at Ringold during October was $100 \mu \mathrm{R} / \mathrm{hr}$, somewhat higher than usual。

The transport rate of ${ }^{46} \mathrm{Sc}$, one of the major contributors to shoreline exposure rates, has been included in Figure 7 and will be reported routinely。 


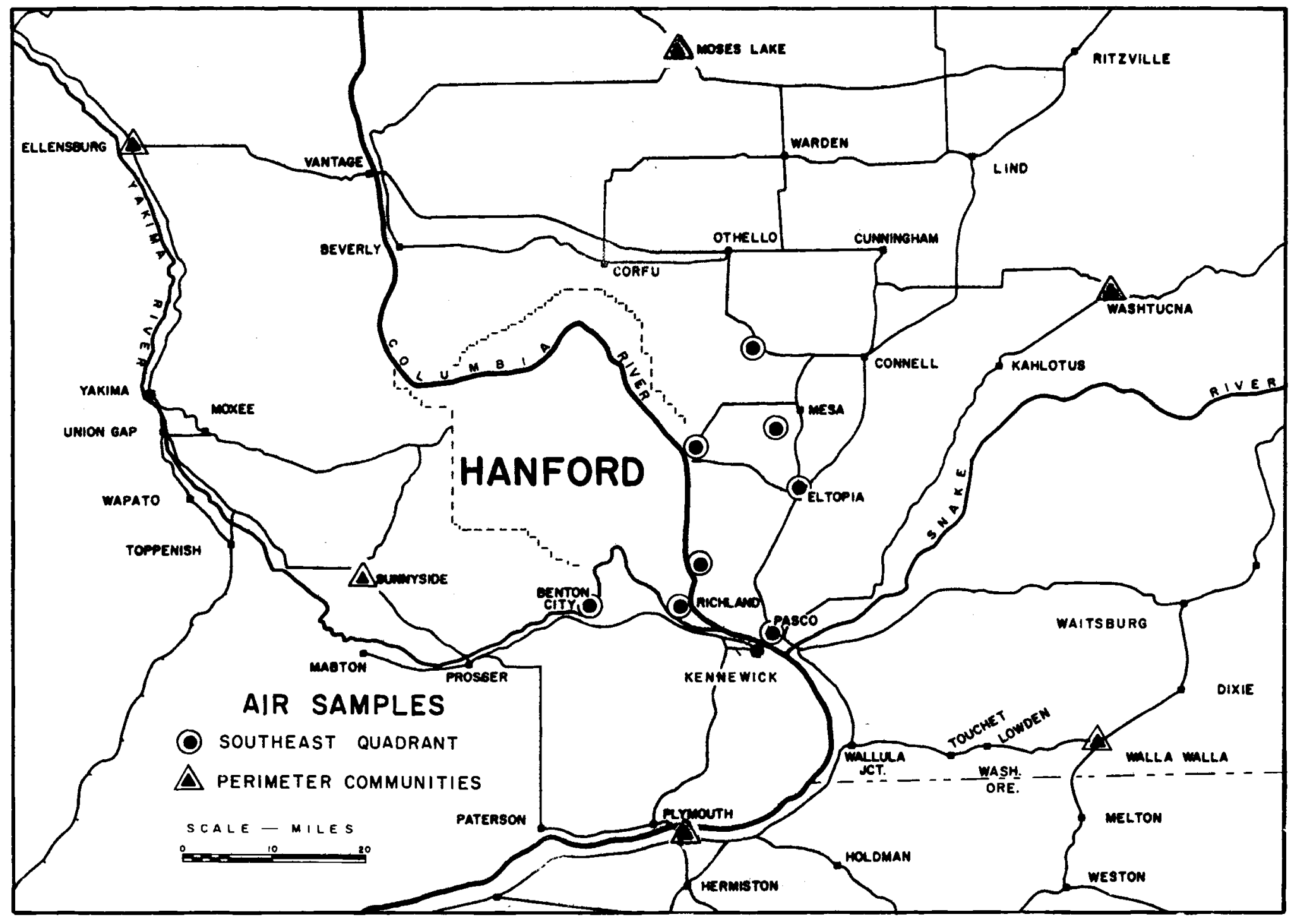

Figure 1

Air Sampling Locations 


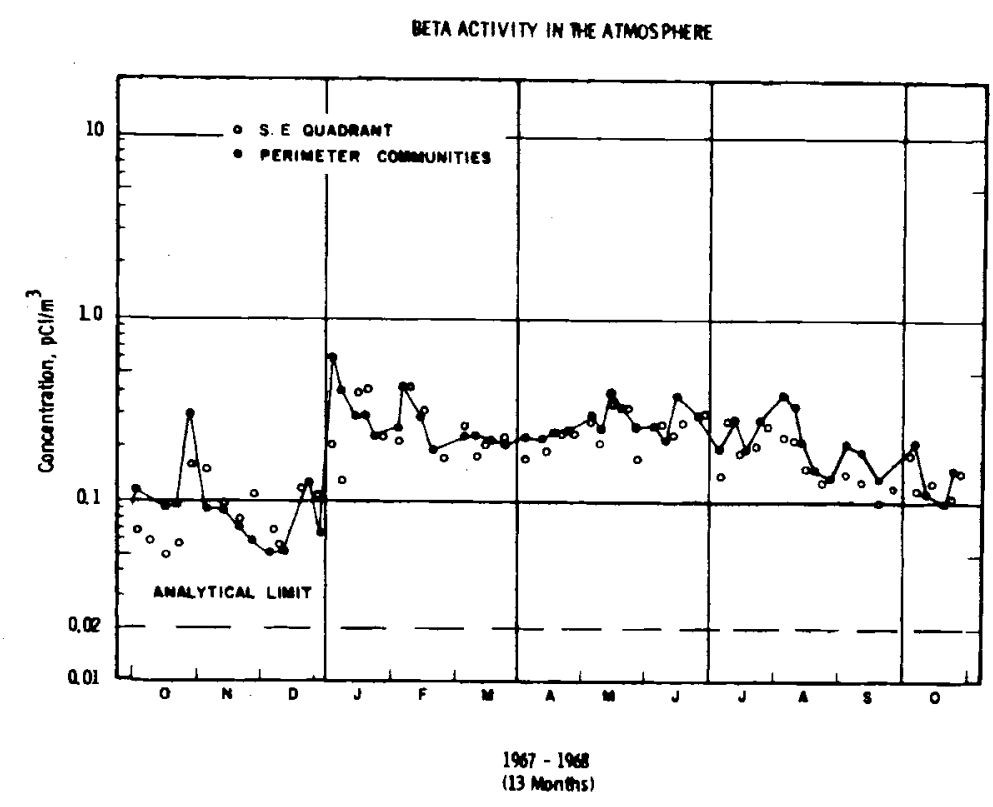

Figure 2

Beta activity in the atmosphere was determined from off-plant air filter samples from near-by locations in the direction of the prevailing wind (Southeast Quadrant), and from other more distant locations (Perimeter Communities). These are shown on Figure 2. Beta concentrations in the atmosphere in October were generally lower than in the early part of 1968. This decrease was attributed to a reduction in the amount of fallout.

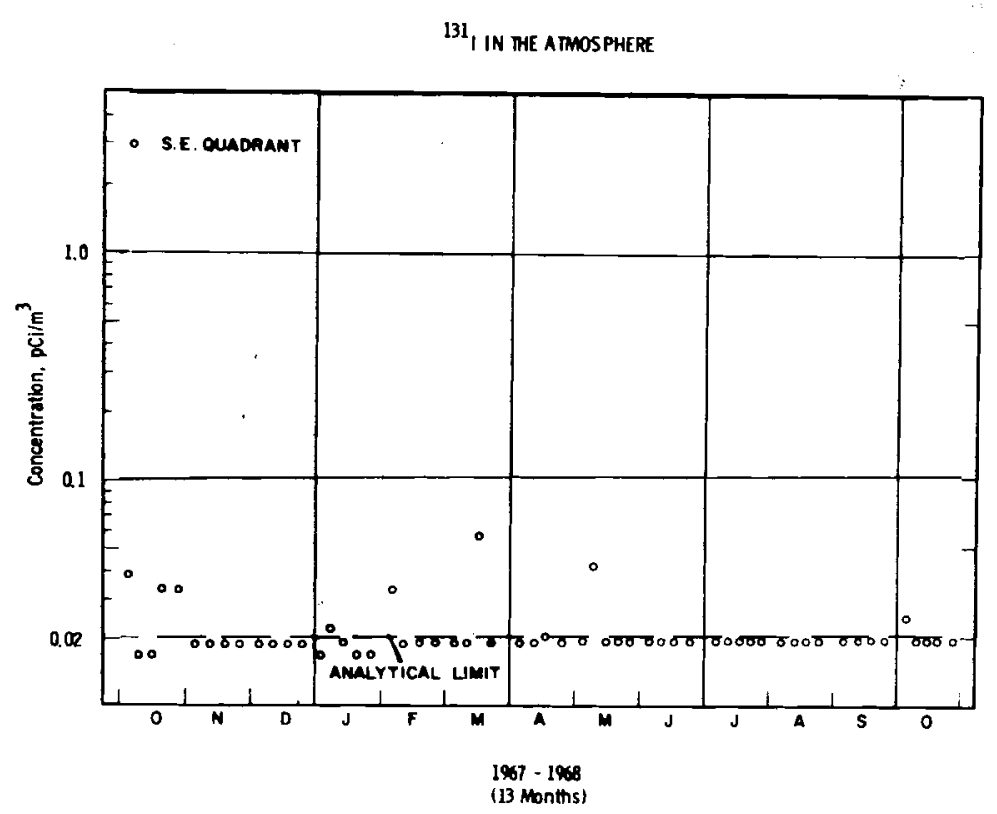

Figure 3

Radioiodine in the atmosphere was determined from caustic scrubbers operated at off-plant sampling locations (Southeast Quadrant). During October, ${ }^{131}$ I concentrations were at or belor the analytical limit $\left(0.02 \mathrm{pCi} / \mathrm{m}^{3}\right)$. The 131 I detected in a few samples in early october was attributed to slightly increased release rates at the laboratory area and at the separations areas. 


\section{I IN LOCALIY PURCHASED MILK}

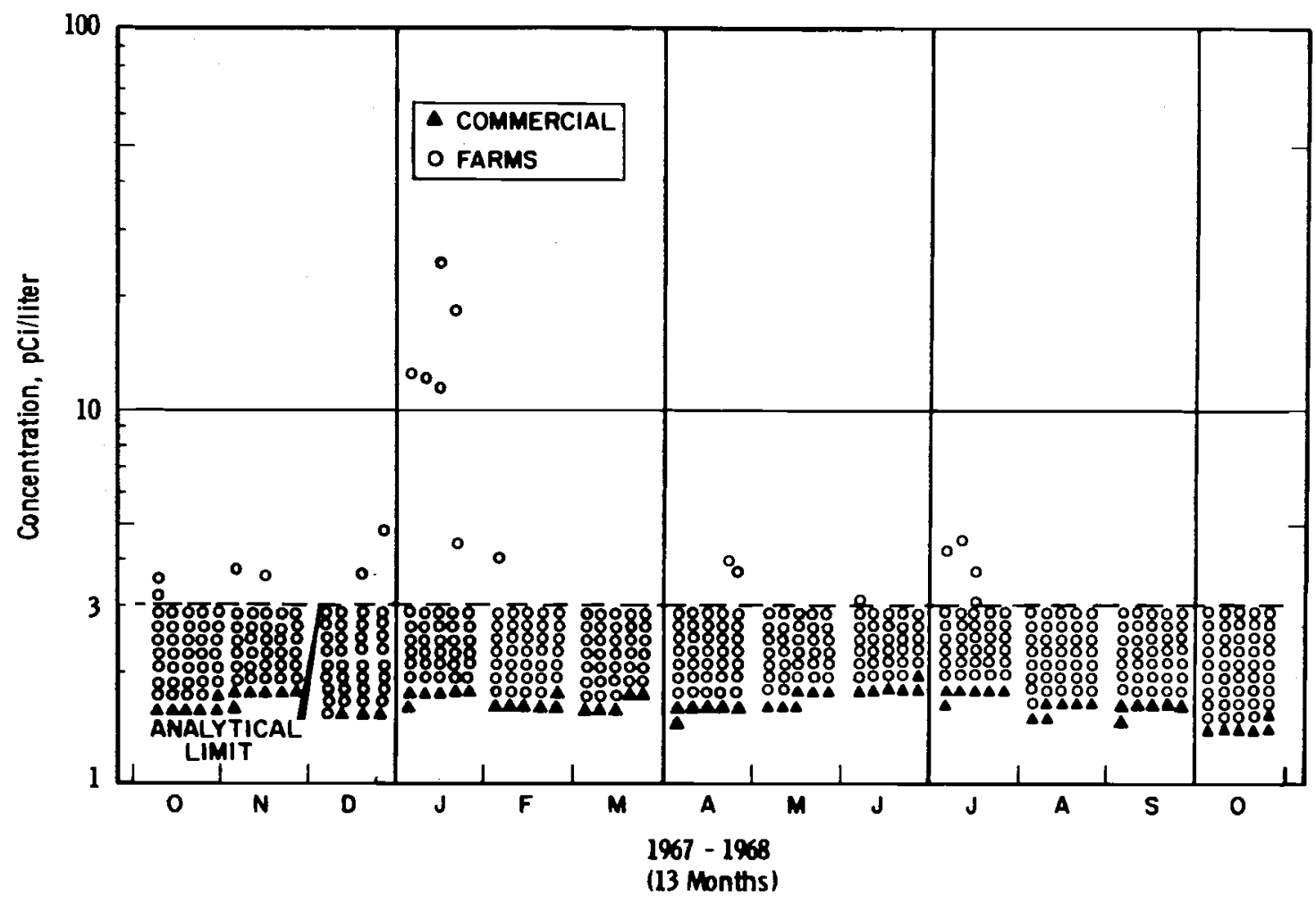

Figure 4

Milk is sampled from individual farms near the Hanford project, from a local creamery tinat collects milk from several producers near the Hanford perimeter, and from local stores. Radioiodine concentrations in all milk samples collected in October were at or below the analytical limit ( $3 \mathrm{pCi}$ ${ }^{1{ }^{1}} \mathrm{I} / l$ ). (Data for other radionuclides in milk are presented in Figures 14-15). 
COLUMBIA RIVER FLOW RATE AT PRIEST RAPIDS

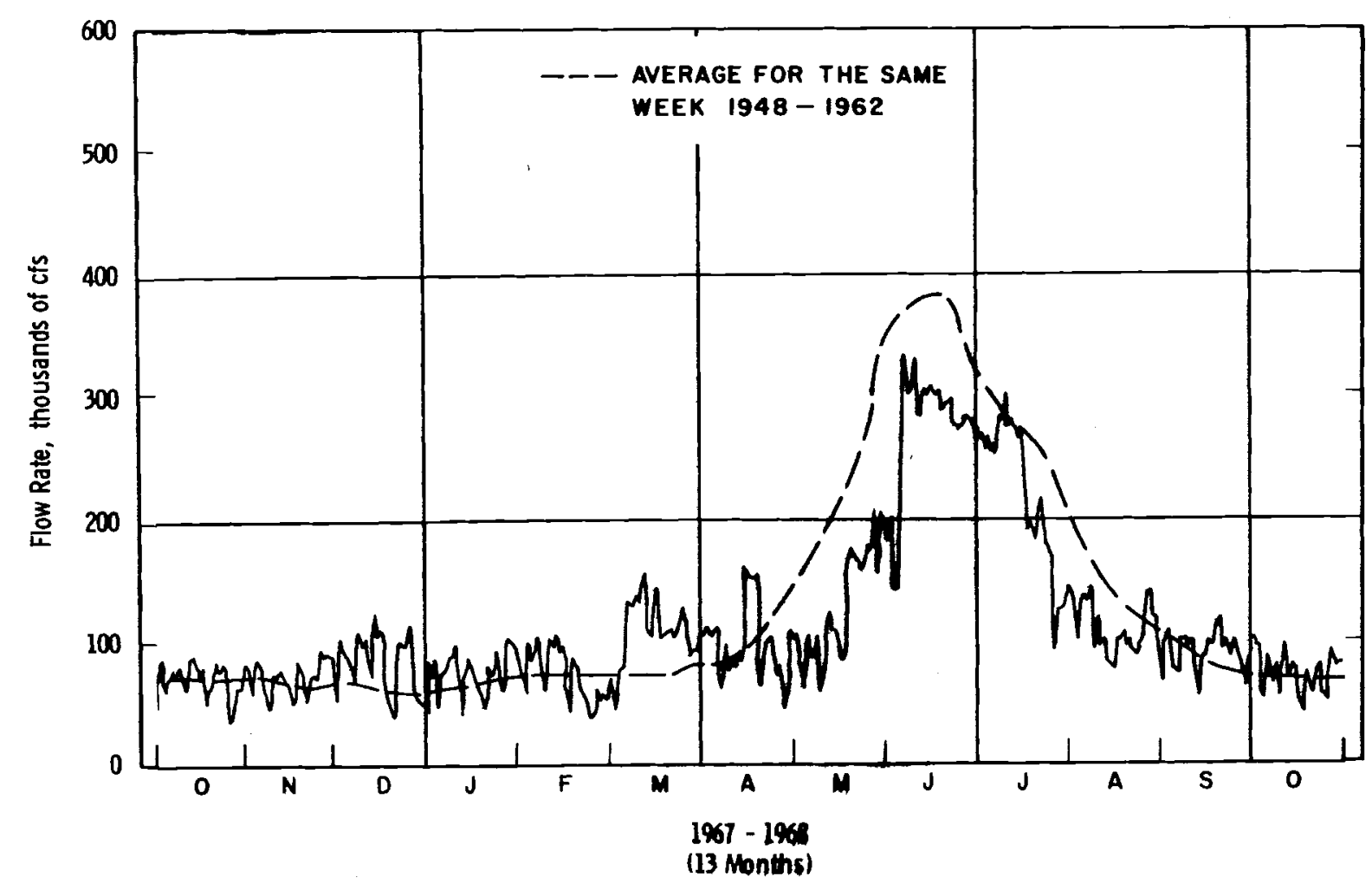

Figure 5

The average river flow rate during October, 1968, was 77,000 cubic feet per second, according to U. S. Geological Survey Reports for the Priest Rapids Gauge Station. The peak mean daily flow rate for the month was 104,000 cubic feet per second on october 1. For comparison, the average river flow rate during October, 1967, was 72,000 cubic feet per second. 
TRANSPORT RATE OF RADIONUCLIDES IN COLUMBIA RIVER AT RICHLAND (CUMULATIVE SAMPLES)

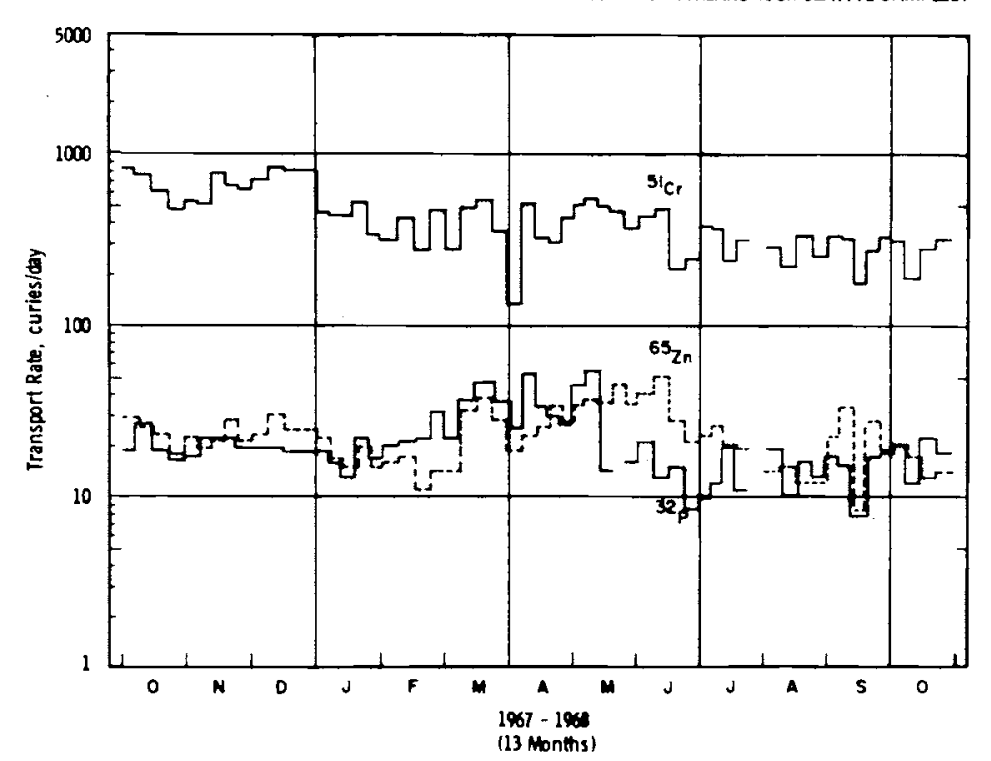

Figure 6

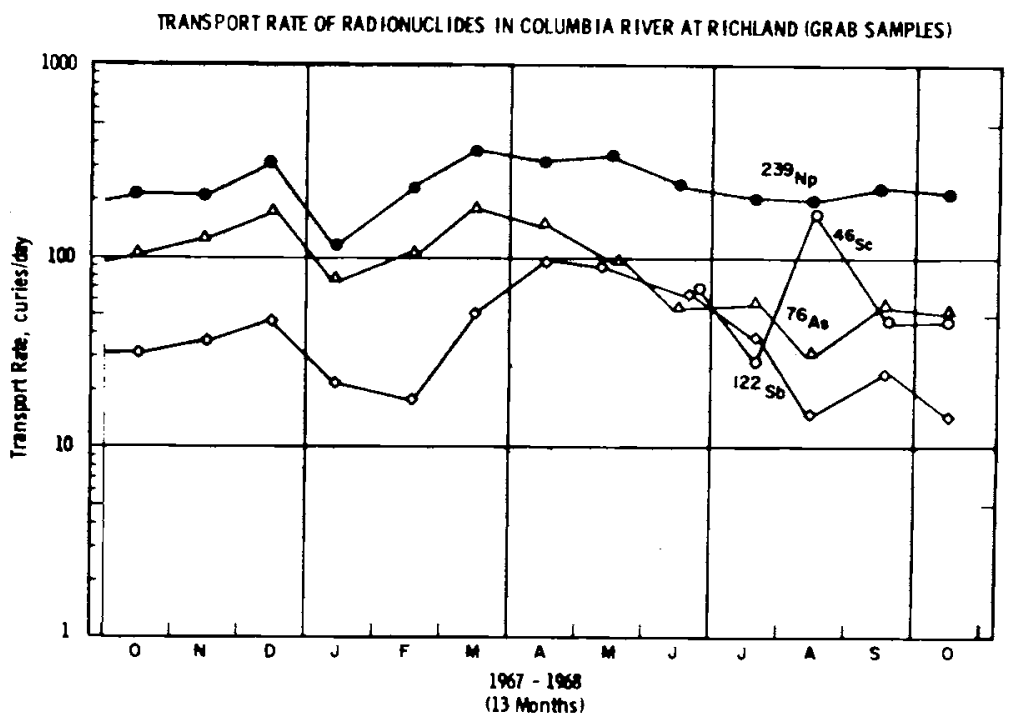

Figure 7

Transport rates for several radionuclides are calculated from concentrations at Richland and Columbia River flow rates at the Priest Rapids Gauge Station. The average ${ }^{51} \mathrm{Cr}$, ${ }^{76} \mathrm{As}$, and ${ }^{122} \mathrm{Sb}$ transport rates for October, 1968, were about one-half the comparable values for the period a year ago. The average transport rates for the other radionuclides shown were similar to the comparable values for a year ago. The transport rate of ${ }^{46} \mathrm{Sc}$ ( 84 day half-life) has been added to Fioure 7 . The principal significance of ${ }^{46} \mathrm{Sc}$ in the environs of Hanford lies in its contribution to shoreline contamination and subsequent exposure rates. 


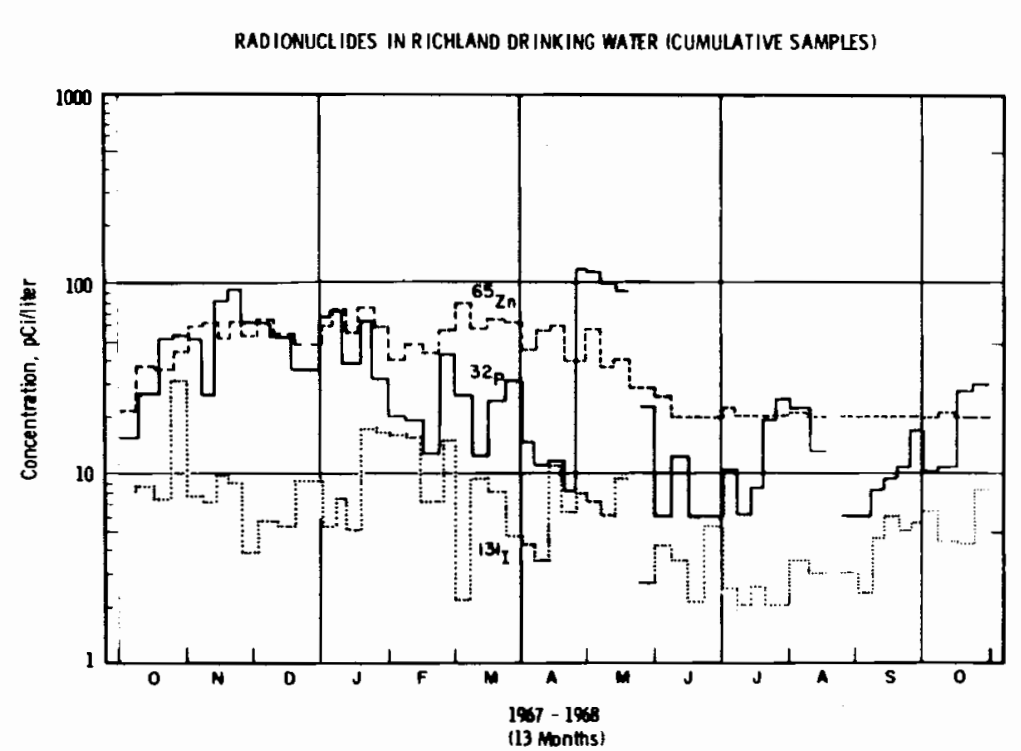

Figure 8

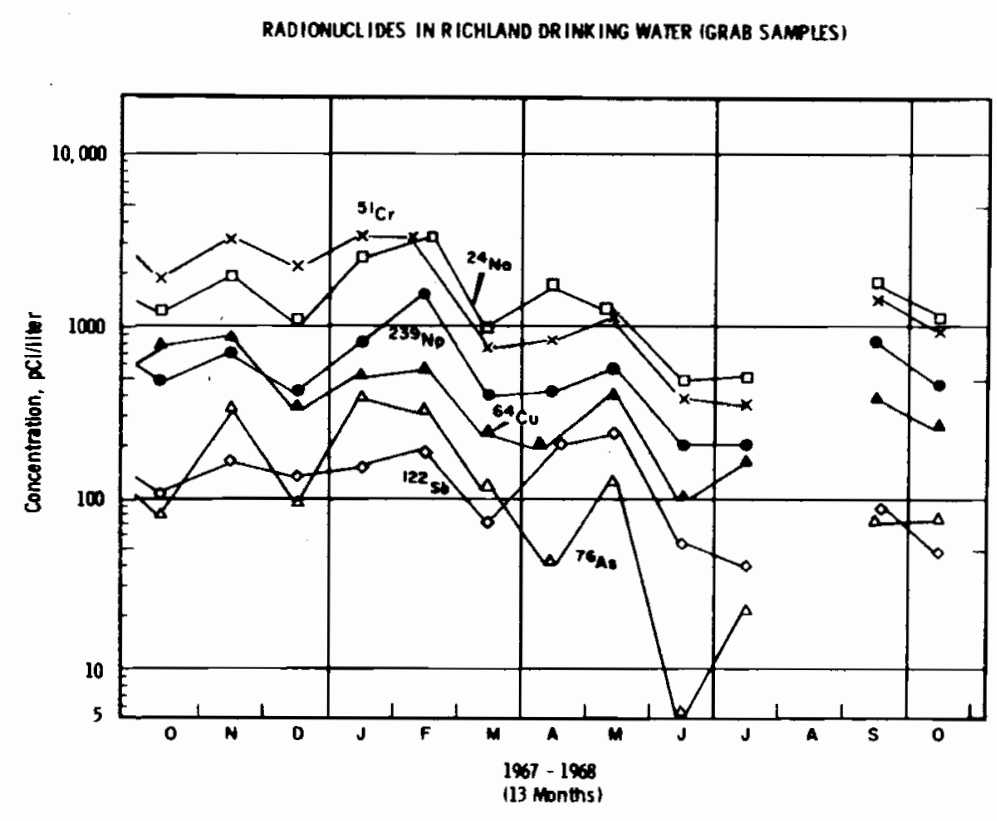

Figure 9

The concentrations of ${ }^{65} \mathrm{zn}$ in october samples of Richland drinking water were at or below the analytical limit. The average concentrations of other radionuclides shown were at or below the comparable values for a year ago. 


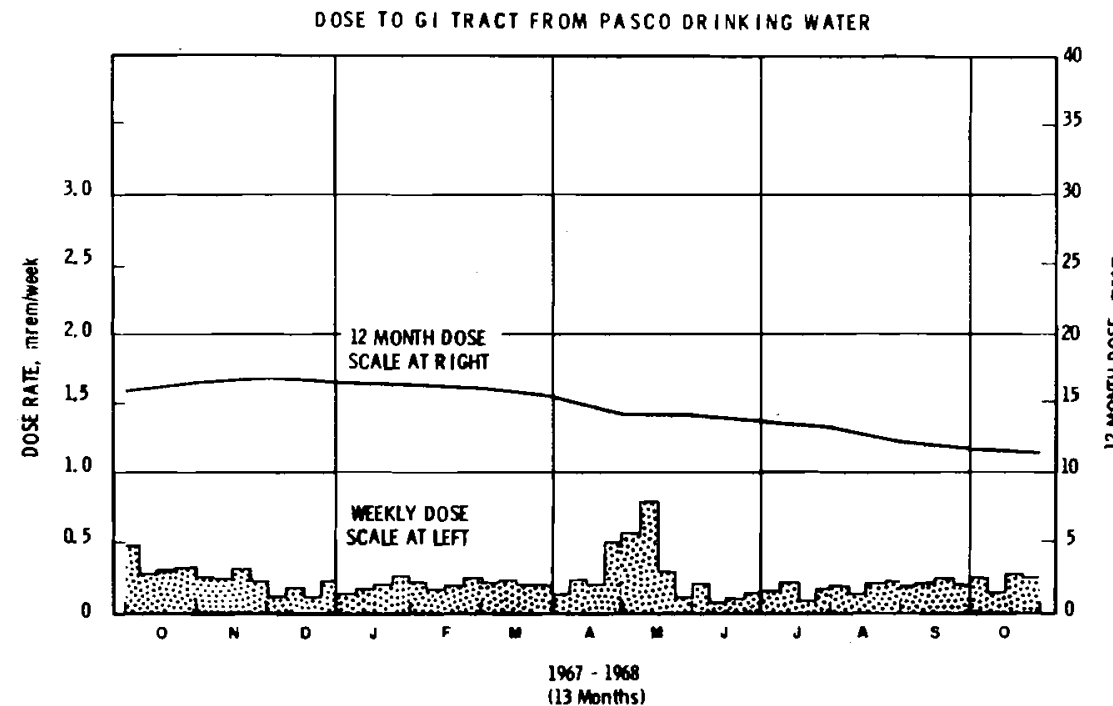

Figure 10

The cumulative 12-month dose to the GI tract from Richland drinking water was estimated to be 22 mrem through october, 1968, compared to 29 mrem through October, 1967. Estimates were based on an assumed intake rate of 1.2 l/day.

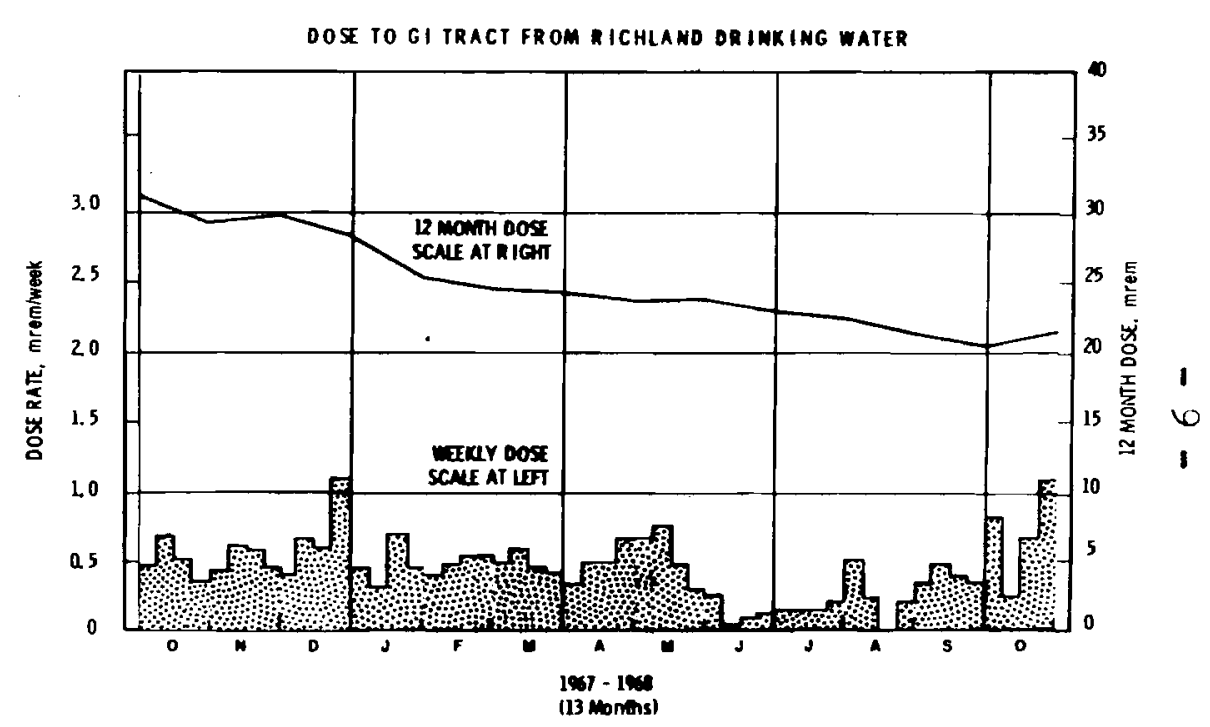

Figure 11

Through October, 1968, the cumulative 12month GI tract dose from Pasco drinking water was 11 mrem compared to $16 \mathrm{mrem}$ through october, 1967. Estimates were based on an assumed intake of $1.2 \mathrm{\ell} /$ day. 


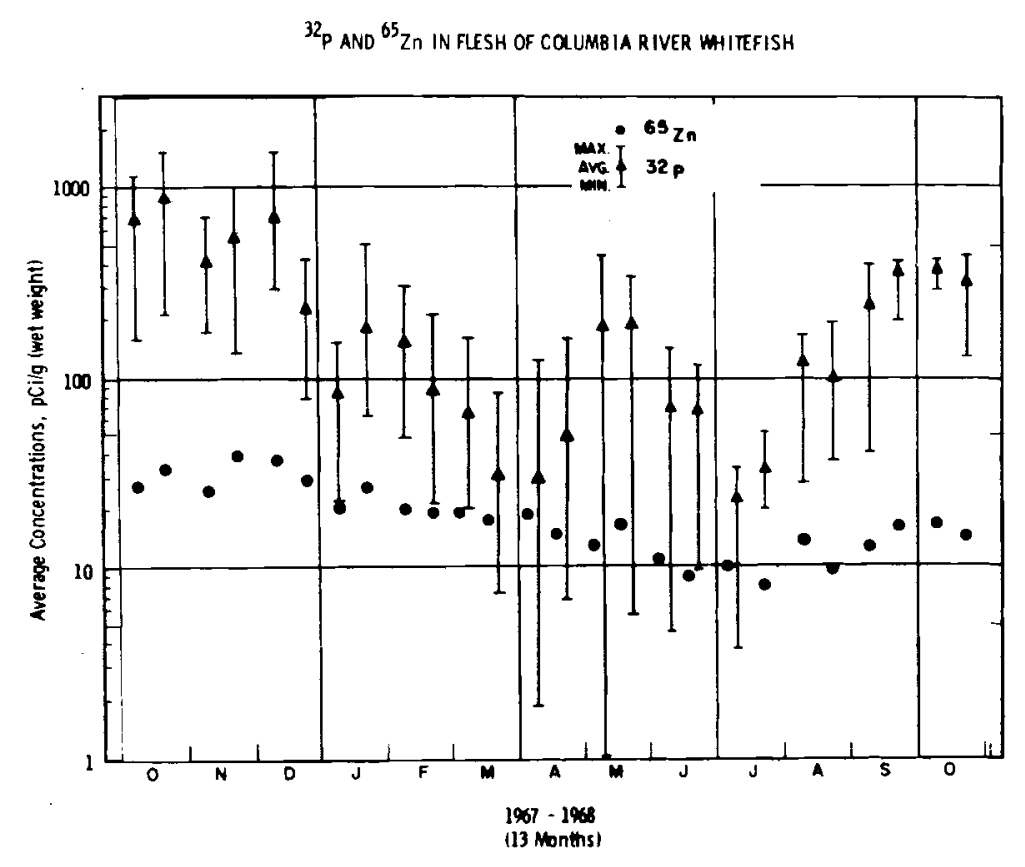

Figure 12

Columbia River whitefish are collected twice monthly from the stretch of the river above Richland. During October, 1968, average ${ }^{32} \mathrm{P}$ and ${ }^{65} \mathrm{Zn}$ concentrations were significantly below comparable 1967 values.

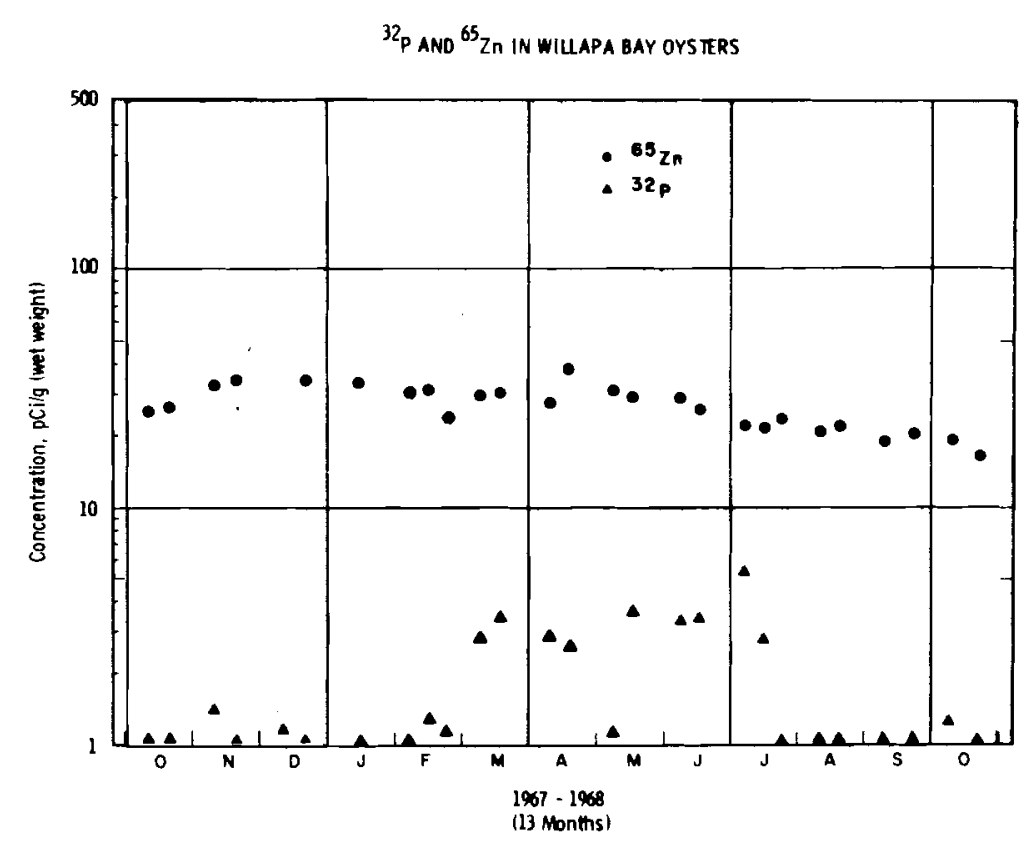

1
5
1

Figure 13

$65 \mathrm{Zn}$ concentrations in Willapa Bay oysters were slightly lower than those observed a year ago. The expected seasonal low ${ }^{32} \mathrm{P}$ concentrations continued through October. 


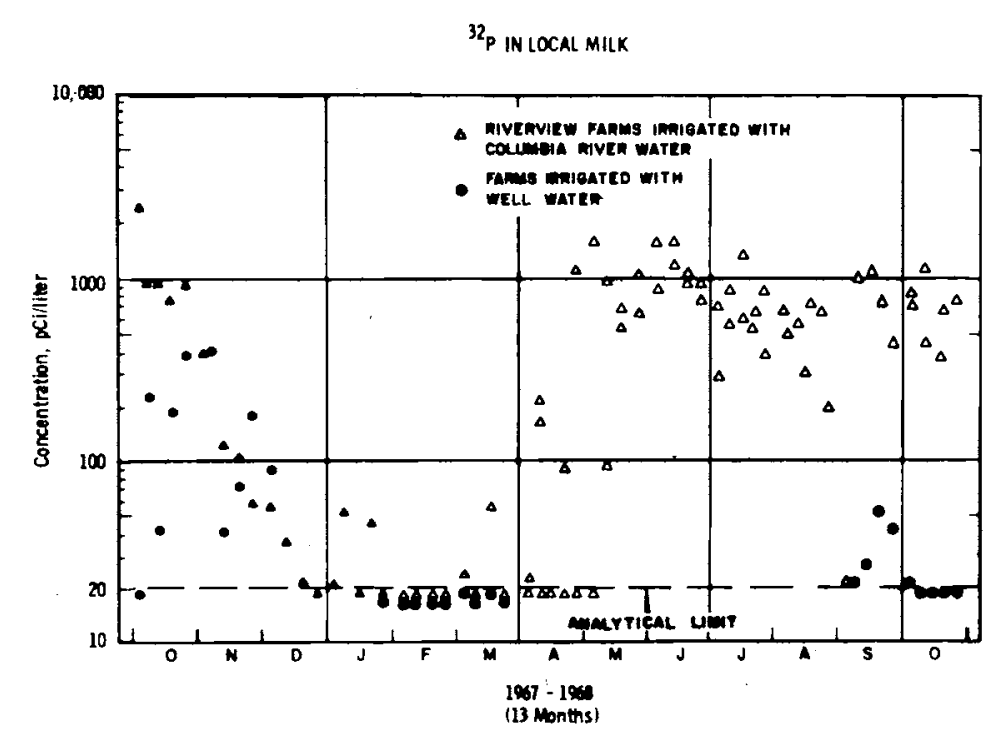

Figure 14

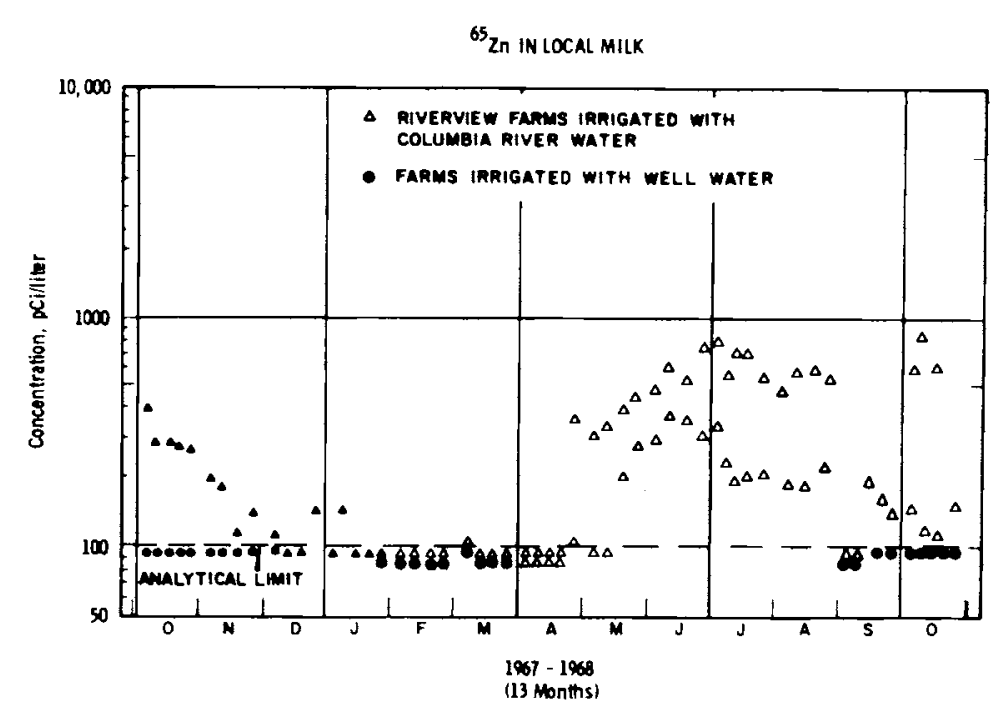

Figure 15

Seasonal use of Columbia River water drawn from below the Hanford profect results in the presence of ${ }^{32} \mathrm{P}$ and ${ }^{65} \mathrm{zn}$ in some local farm milk. Milk from river-irrigated farms situated in the Riverview district (upstream from Pasco) is routinely sampled. Figures 14 and 15 include, for comparison, analyses of milk from a near-by farm using well water. During October, concentrations of ${ }^{32} \mathrm{P}$ and ${ }^{65} \mathrm{Zn}$ were at expected levels. 


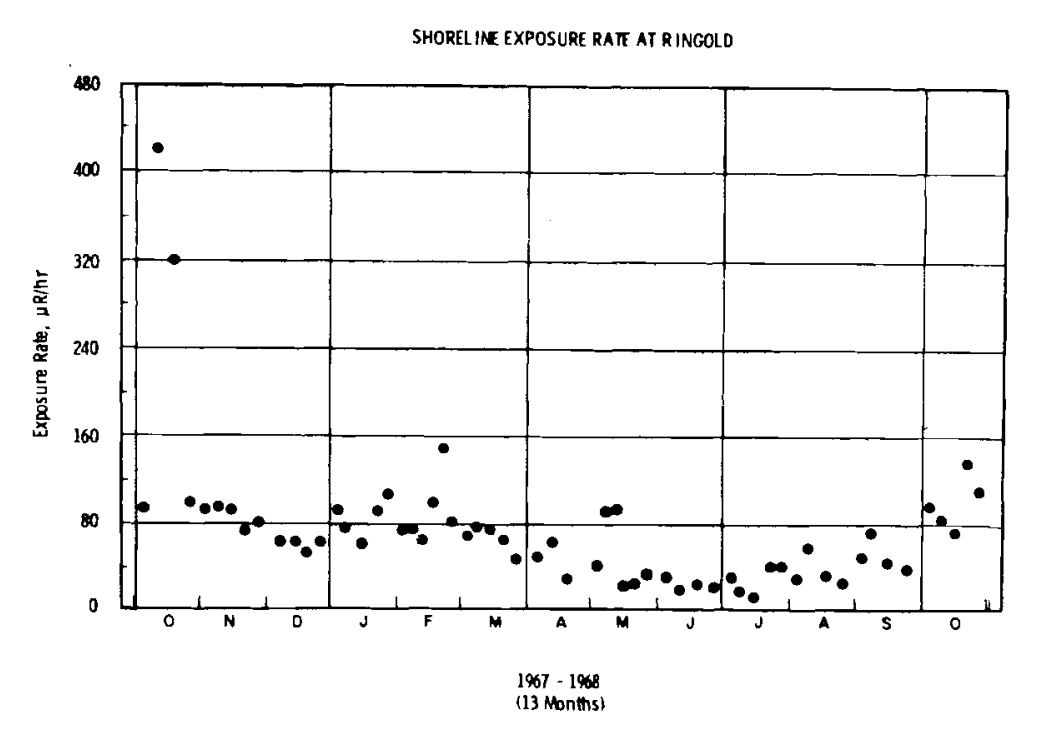

Figure 16

Gamma radiation exposure rates at the Columbia River shoreline are measured with a 40-l ionization chamber (radium-gamma calibration in $\mu \mathrm{R} /$ hour). The measurements are made 3 feet above ground, approximating the dose rate to the gonads of a person standing on the riverbank. The closest point of public access to the river shoreline downstream from the reactors is about 5 miles above the Ringold location during hunting season. The average measurement was $100 \mu \mathrm{R} / \mathrm{hr}$ during October, 1963.

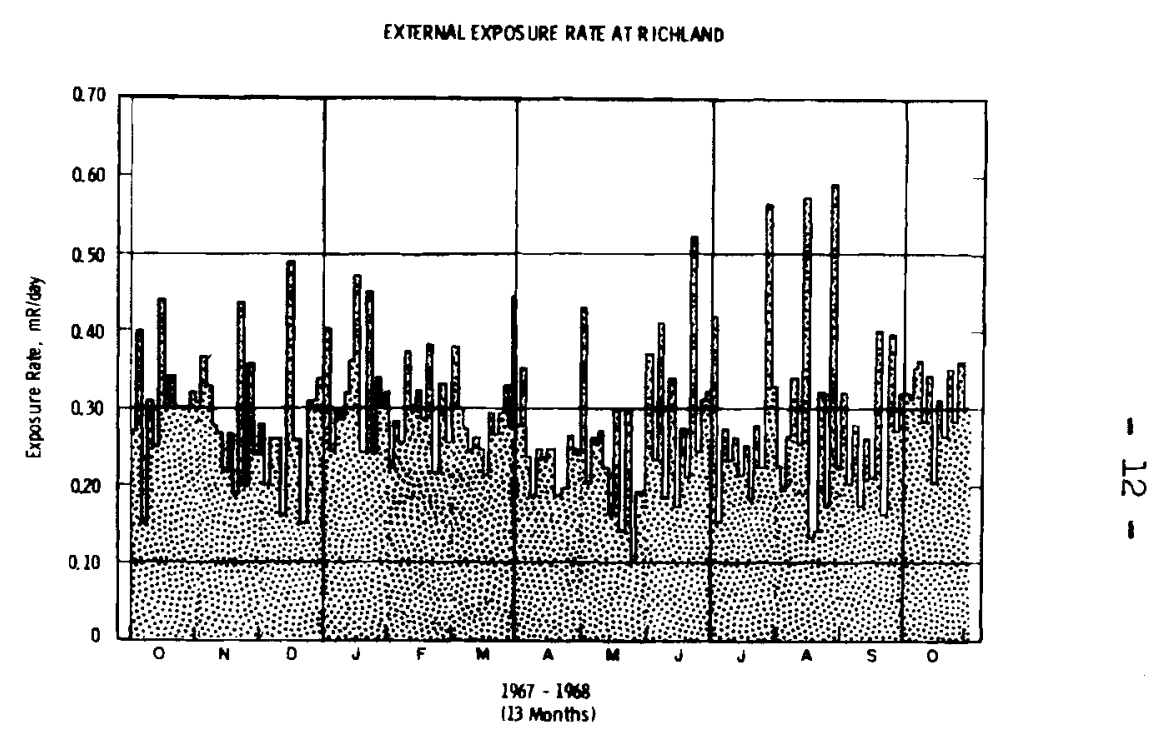

Figure 17

External gamma exposure rates in the city of Richland are measured with small ionization chambers. The average for October, 1968, was $0.31 \mathrm{mR} /$ day. The measured exposure rates over the twelve months ending with October averaged $0.28 \mathrm{mR} /$ day which was not significantly different from the comparable average for a year ago. 
IEMPERATURE OF THE COLUMBIA RIVER AI PRIES T RAP IOS

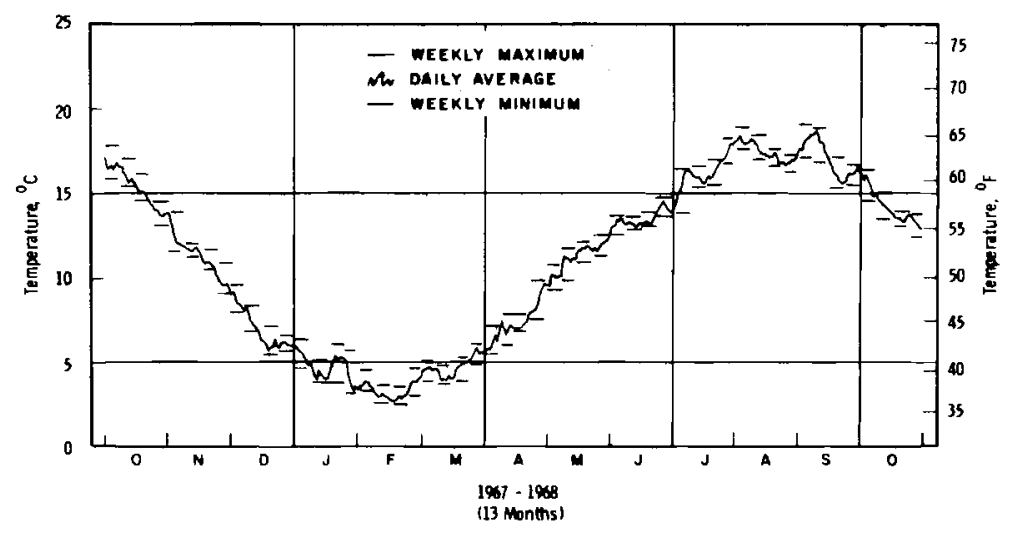

Figure 18

The temperatures plotted in Figure 18 are measured at the Priest Rapids Gauge Station.

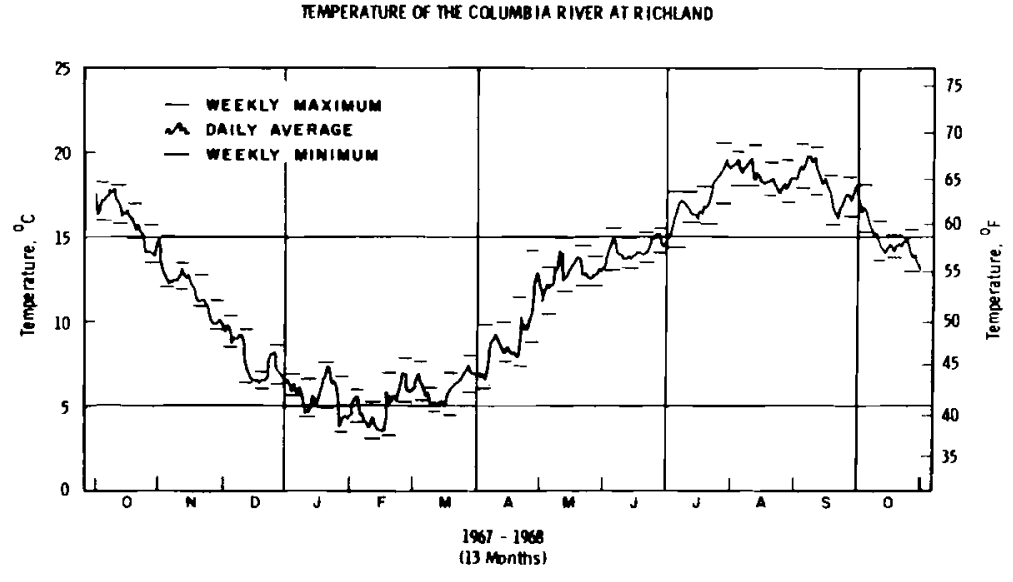

Figure 19

The temperatures plotted in Figure 19 are measured at the Richland Water Plant intake. 
NITRATE ION IN COUUMBIA RIVER WATER
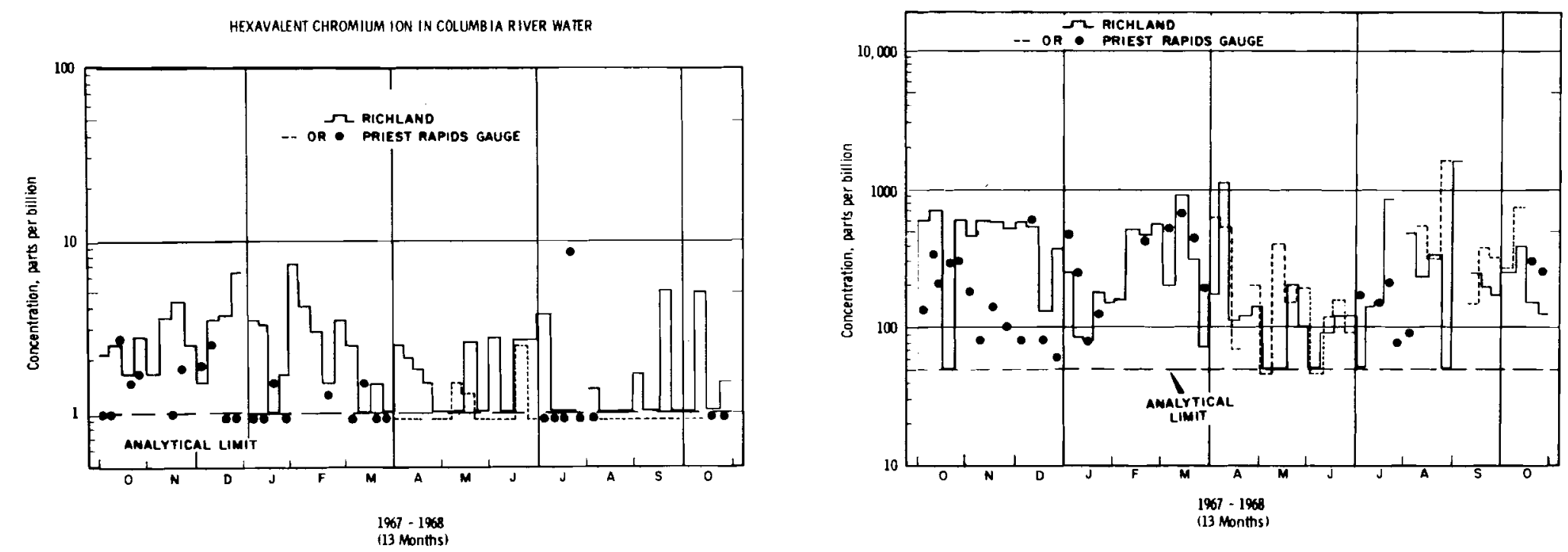

Figure 20

Figure 21

Concentrations of hexavalent chromium ion and nitrate ion were determined from grab samples at the Priest Rapids Guage Station (upstream from Hanford) and from cumulative samples at the Richland Water Plant intake. Dichromate ion is added during the treatment process for reactor cooling water. Some nitrate ion from chemical wastes discharged to the pround may enter the river with underground water. For drinking water, the Public Health Service standards (1962) include concentration limits of 50 parts per billion as hexavalent chromium and 45,000 parts per billion as nitrate ion. 
TABLE 1

CHEMICAL CHARACTERISTICS OF COLUMBIA RIVER WATER

Results for October, 1968, of analyses of river water collected at Vernita Bridge and the 100-F Area (above and below the production reactors) as reported by DouglasUnited Nuclear。

(Results in ppm)

\begin{tabular}{|c|c|c|c|c|c|c|c|c|c|c|c|c|}
\hline Vernita & $\mathrm{Mg}$ & $\mathrm{Fe}$ & $\mathrm{Cu}$ & $\mathrm{Ca}$ & $\mathrm{SO}_{4}$ & $\mathrm{PO}_{4}$ & $\mathrm{CI}$ & $\begin{array}{c}\text { Diss. } \\
\mathrm{O}_{2}\end{array}$ & $\begin{array}{l}\text { Phth。 } \\
\text { Alk。 }\end{array}$ & $\begin{array}{l}\text { M。O } \\
\text { Alk. }\end{array}$ & Hardness & Solids \\
\hline $10-8-68$ & 3 & .03 & .003 & 23 & II & .02 & .15 & 10.6 & 0 & 52 & 70 & 76 \\
\hline $10-22-68$ & 3 & .01 & ND & 24 & 11 & .04 & .35 & 9.6 & 1 & 49 & 72 & 82 \\
\hline
\end{tabular}

100-F Area

$\begin{array}{lllllllllllll}10-8-68 & 3 & .02 & .009 & 24 & 11 & .01 & .25 & 9.8 & 0 & 51 & 71 & 78 \\ 10-22-68 & 3 & .02 & .010 & 25 & 10 & .05 & .30 & 9.0 & 0 & 52 & 74 & 83\end{array}$

ND - Not detected. 


\section{DISTRIBUTION}

Number

of Copies

$4 \mathrm{ARHCO}$, Inc Richland, Washington 99352

G。E。Backman

B. Jo McMurray

H。 I。 Maxfield

Files

2 Atomic Energy Commission,

Washington

Division of Biology and Medicine

$J \circ N_{0}$ Wolfe

Division of Operational Safety

M。 B。 Biles

6 Atomic Energy Commission Richland Operations Office

$$
\begin{aligned}
& A_{\circ} \text { Brunstad } \\
& W_{\circ} \text { Devine, Jr。 } \\
& W_{\circ} E_{\circ} \text { Lotz } \\
& C_{\circ} L_{\circ} \text { Robins on } \\
& R_{\circ} B_{\circ} \text { St。 John } \\
& M_{\circ} W_{\circ} \text { Tiernan }
\end{aligned}
$$

1 Diviston of Technical Information Extension

2 AEC, Chicago Patent Group

$G \circ H$ 。 Lee

$R_{0} K_{0}$ Sharp

8 Douglas-United Nuclear

Richland, Washington 99352

D。 A。 Baker

Po A。 Carlson

Co Do Corbit

$R_{0} G_{0}$ Geier

W. So Nechodom

I。F。Reilly

Files
Number

of Copies

5 Federal Water Pollution Control Administration 570 Pittock Block Portland, Oregon 97205

$$
R \text { 。 } F \text { 。 Poston }
$$

1 Federal Water Pollution Control Administration Division of Pollution

Surveillance 1014 Broadway Cincinnati, Ohio 45202

$$
D \circ G \circ \text { Ballinger }
$$

1 Federal Water Pollution Control Administration Physical \& Engineering Sciences Section TA\&I

$U_{0} S_{0}$ Depto of the Interior Cincinnati, Ohio 45213

$$
\text { Mo } W_{0} \text { Lammering }
$$

1 Hanford Environmental Health Foundation Richland, Washingt on 99352

$$
F_{0} E_{0} \text { Adley }
$$

1 ITT-Federal Support

$$
\text { Services, Inco }
$$

Richland, Washington 99352

$$
\mathrm{R} \text { 。 } \mathrm{H} \text { 。Wils on }
$$

$1 J_{0} A_{0}$ Jones Construction $\mathrm{Co}_{0}$ Richland, Washington 99352

$$
\text { I。C。 Roos }
$$


Number

of Copies

1 New York State Department of Health

Division of Environemntal

Health Services

845 Central Avenue

Albany, New York 12206

W。 Jo Kelleher

1 Oregon State Board

of Health

$1400 \mathrm{~S}_{0} \mathrm{~W}_{0} 5 \mathrm{th}$ Avenue

Portland, Oregon 97201

$\mathrm{K}$ 。 $\mathrm{H}$ 。 Spies

1 Oregon State University Department of Oceanography Corvallis, Oregon 97331

$$
\text { W。 O. Forster }
$$

1 Reed College

Department of Chemistry Portland, Oregon 97202

$$
A_{\circ} F_{\circ} \text { Scott }
$$

$1 \quad U_{0} S_{0}$ Public Health Service

National Center for

Radiological Health

12720 Twinbrook Parkway

Rockville, Maryland 20852

Chief, Standards and Intelligence Branch

$1 \quad U_{0} S_{0}$ Testing Company 2800 George Washington Way Richland, Washingt on 99352

D。 $B_{0}$ Wilcox

1 University of Washington College of Fisheries Laboratory of Radiation Ecology Seattle, Washington 98105

A。 $H_{\circ}$ Seymour
Number

of Copies

2 Washington State Pollution Control Commission P. 0. BOX 829

Olympia, Washington 98501

A。 T. Neale

$G$ o $H_{0}$ Hansen

1 Washington State Pollution Control Commission 321 Hutton Bldg. Spokane, Washington 99204

1 Washington State Department of Health

1510 Smith Tower

Seattle, Washington 98104

28 Battelle-Northwest

D. Wo Alton

P. Jo Blumer

$J \circ P$ 。 Corley

$D_{0} H_{0}$ Denham

To Ho Essig

W。 L。 Fisher

$R_{0} F_{0}$ Foster

$\mathrm{R}$ 。 $\mathrm{B}$ 。 $\mathrm{Hall}$

$K_{0}$ R。 Heid

$M_{0} M_{0}$ Hendrickson

J. F。 Honstead

$W$. C. Horton

$\mathrm{R}$ 。 $\mathrm{T}$ 。 Jaske

$J_{0} J_{0}$ Jech

R. L. Junkins

$H . V$. Larson

$J \circ M_{0}$ Nielsen

C。 L。 Simpson

$J$ o K. Soldat

W. L。 Templeton

C。 $M_{0}$ Unruh

F。 Wo Woodfield

$C$ 。 $B$ 。 Wooldridge

Technical Information 